\title{
A LEI 13.245/16 E O CARÁTER INQUISITIVO DO INQUÉRITO POLICIAL
}

\author{
THE 13,245/16 LAW AND INQUISITIVE CHARACTER OF POLICE INVESTIGATION
}

\author{
Sthephanie Gabrielle Dosso ${ }^{1}$ \\ Fernanda Garcia Velasquez ${ }^{2}$
}

'Bacharelanda em Direito pela Universidade Paranaense - UNIPAR - Umuarama - PR. E-mail: Sthephaniegabrielle@hotmail.com

${ }^{2}$ Bacharel em Direito pela Faculdade de Direito da Alta Paulista, Mestre em Direito Processual e Cidadania/UNIPAR. Atualmente é Diretora do Núcleo dos Institutos de Ciências Humanas, Letras e Artes, de Ciências Sociais Aplicadas; e de Educação, e Professora Adjunta da Universidade ParanaenseUNIPAR - Umuarama - PR.

E-mail: fernanda@prof.unipar.br
Recebido em novembro de 2017 Aceito em março de 2018
DOSSO, S. G.; VELASQUEZ, F. G. A lei 13.245/16 e o caráter inquisitivo do inquérito policial. Akrópolis Umuarama, v. 26, n. 2, p. 195-208, jul./dez. 2018.

\section{DOI: 10.25110/akropolis.v26i2.7459}

Resumo: Objetivou-se com este trabalho analisar o inquérito policial com suas características e peculiaridades, procurando demonstrar as principais mudanças e discussões oriundas da Lei 13.245/16. A priori, é necessário observar os princípios constitucionais, com ênfase no contraditório e ampla defesa. Considerando-se que existe uma discussão entre profissionais da área do direito, em que uns dizem que essa lei gerou vantagens para investigados, e outros dizem ser apenas ampliação do direito de acesso ao inquérito por parte dos profissionais. Após uma análise minuciosa das ponderações do advento da Lei 13.245/16, que ixnovou principalmente a questão do acesso ao inquérito por parte do advogado, o sigilo relativo ao inquérito e a nulidade dos atos probatórios. Evidenciou-se que o advogado terá mais acesso ao inquérito policial; que os advogados terão acesso apenas às provas e discussões já anexadas no inquérito. Além disso, os questionamentos ao investigado só far-se-ao após a desistência da assistência jurídica. Contudo, é necessário que essa lei seja mais estudada, para que haja equilíbrio entre o acesso e o sigilo do inquérito, para não prejudicar o seu andamento, nem a utilidade das provas. Porém, é necessário assegurar aos investigados mais proteção ao princípio da não autoincriminação. Nota-se que o processo inquisitorial não sofrerá mudanças significativas, nem deixará de ser inquisitivo, pois não existem, nestes casos, os princípios do contraditório e de ampla defesa.

Palavras-chave: Processo Penal; Ampla Defesa; Contraditório; Inquérito Policial; Sigilo do Inquérito.

Aвstract: the objective of this work were to examine the police investigation with its characteristics and peculiarities, seeking to demonstrate the main changes and discussions from the 13,245/16 Law. A priori, it is necessary to observe the constitutional principles, with emphasis on the contradictory and ample defense. Considering that there is a discussion among professionals in the area of Law, where some say that this law has generated benefits to indicted ones, and others say to be just expansion of the right of access to inquiry on the part of professionals. After a thorough analysis of the weightings of the advent of $13,245 / 16$ law, which innovated mainly the question of access to inquiry by the lawyer, the secrecy regarding the investigation and the nullity of the acts evidence, it was evidenced that the lawyer will have more access to police investigation; that lawyers will have access only to the evidence and arguments already attached in the investigation; the questionings to the investigated will only happen after the withdrawal of legal aid. However, it is necessary that this law is more studied, so that there is balance between access and the secrecy of the investigation, not to harm its progress, or the usefulness of its evidence, but it is 
necessary to ensure the investigated more protection to principle of non self imputation . In particular, to be noted that the inquisitorial process will not suffer significant changes, or stop being inquisitive, because do not exist in these cases, the principles of contradiction and ample defense. For this study, it was used as methodology the bibliographical research, with the use of specific material including documents, monographs, dissertations and books, the latter being the main primary source.

Keywords: Ample Defense; Contradictory; Criminal Proceedings; Police Investigation; Secrecy of the investigation.

\section{INTRODUÇÃO}

O Brasil por ser um Estado Democrático de Direito, possui o poder de ditar regras de convivência para manter a paz e garantir a proteção dos bens jurídicos considerados imprescindíveis. Mas, embora esse poder seja inerente ao Estado, ele não é absoluto e encontra limitações. Por essa razão é que surge o Direito Processual Penal, um instrumento destinado à realização do poder punitivo do Estado, cujo desenvolvimento é regido por um conjunto de normas, preceitos e princípios com intuito evitar a prática de atos arbitrários ou atentatórios contra às liberdades e garantias individuais previstas na Constituição Federal.

Ao Estado é conferido variadas normas que permitem que órgãos estatais investiguem e procurem encontrar ilícitos penais ou extrapenais. Desse modo, surge o inquérito policial, o principal instrumento investigatório no campo penal, cuja finalidade precípua é estruturar, fundamentar e dar justa causa a ação penal.

Ante ao exposto, o inquérito policial é instrumento investigatório, sigiloso, com caraterísticas meramente informativas e administrativas, não encontrando respaldado nos princípios do contraditório e da ampla defesa, uma vez que não julga nem mesmo acusa. Nesse diapasão, vale ressaltar que desde a instauração do inquérito policial, esse sempre foi alvo de discussões, por se tratar de um instrumento polêmico, com o advento da Lei 13.245/16 tal situação não se extirpou.

Portanto, o presente trabalho objetiva analisar o sigilo no inquérito policial frente ao direito do investigado, uma vez que os princípios constitucionais devem ser seguidos em prol de sua dignidade. Por outro lado, procurar-se-á demonstrar no presente trabalho uma análise so- bre o advento da Lei $n^{\circ} 13.245 / 16$ e o direito do advogado em acessar os autos já produzidos no inquérito, amparado anteriormente pela Súmula Vinculante $\mathrm{n}^{\circ} 14$ do STF.

No decorrer do trabalho será evidenciado que mesmo com caráter sigiloso do inquérito policial é necessário manter a integridade e dignidade do investigado. E além do mais, o advento da Lei $n^{\circ} 13.245 / 16$ veio para salvaguardar o que já estava previsto em nosso ordenamento jurídico, trazendo assim ao advogado, a liberdade para consultar os autos do inquérito e ter amplo acesso ao que já foi já documentado.

\section{O INQUÉRITO POLICIAL}

\subsection{Conceito, finalidade e natureza jurídica do inquérito policial}

O Inquérito Policial está presente desde a ldade Média como uma peça para averiguação. Assim, desde a Antiguidade procura-se averiguar a apuração dos delitos praticados no convívio social. Nesse sentido leciona Adilson Mehmeri (1997, p. 04):

Entre os antigos atenienses já se esboçava uma espécie de inquérito para averiguar a probidade individual e familiar dos eleitos magistrados, sendo que dez desses eram os estínomos, os quais trabalhavam como policiais. Tal investigação seria mais uma forma de sindicância, de cunho investigatório, sem qualquer esboço de contraditório. (MEHMERI, 1997, p.04).

A instauração do inquérito policial no Brasil deu-se com a edição da Lei ${ }^{\circ} 261$, em 03 de dezembro de 1841, que modificou o Código de Processo Criminal do Império. Essa modificação atribuiu aos chefes de polícias a competência para instaurar procedimentos de averiguação, ou seja, surgiu como uma investigação prévia de fatos delituosos, que posteriormente, eram registrados em um documento e remetidos ao Juiz de Direito, para a devida verificação da tipificação penal.

Já com a edição da Lei $n^{\circ} 2.033$ em 20 de setembro de 1871, o sistema de persecução penal foi dividido em duas fases, sendo a primeira uma fase preliminar, e a segunda uma fase judiciária, e desde então, o inquérito passou a ser estruturado como uma fase preliminar.

Com o surgimento do Decreto Lei $n^{\circ}$ 
4.824 em 22 de novembro de 19871, o inquérito policial passou a ter a seguinte definição no art. 42 da referida Lei: "O inquérito policial consiste em todas as diligências necessárias para o descobrimento dos fatos criminosos, de suas circunstâncias e de seus autores e cúmplices, devendo ser reduzido a instrumento escrito". Desde então, o inquérito vem servindo como um meio de conter os abusos das autoridades policiais, pois estes, anteriormente, possuíam poderes excessivos.

Com a promulgação da Lei 3.689 em 03 de outubro de 1941, atual Código de Processo Penal Brasileiro, o inquérito policial passou a ter respaldo no artigo $4^{\circ}$, que traz como conceito genérico e amplo que a "polícia judiciária será exercida pelas autoridades policiais no território em suas respectivas circunscrições e terá por fim a apuração das infrações penais e de sua autoria".

Nesse sentido, Aury Lopes Junior (2005, p.135) ressalta que o "inquérito policial nasce da mera possibilidade de que exista um fato punível. E, que, a própria autoria não necessita ser reconhecida no início das investigações. " Portanto, vale ressaltar que mesmo com a instauração do inquérito policial, não pode o investigado perder os direitos e as garantias fundamentais.

Quanto à instauração do inquérito policial, de acordo com o art. $5^{\circ}$, incisos I a II do Código de Processo Penal, ele poderá se iniciar das seguintes maneiras: a) com o auto de prisão em flagrante, ou seja, de ofício, no momento ou logo após a prática do ato delituoso; b) ou atendendo ao requerimento do Ministério Público, do ofendido ou de qualquer pessoa que tenha legitimidade para representá-lo, assim, o inquérito terá início com a notícia do crime;

Quando à autoridade policial toma conhecimento de um fato aparentemente ilícito, chama-se de notitia criminis. Essa notícia é levada ao conhecimento da autoridade por meio do Ministério Público, do ofendido ou de quem possua legitimidade, conforme preleciona o art. 39 do Código de Processo Penal, sendo conhecida como delatio criminis, ou seja, a delatio criminis é a comunicação feita por quem tem legitimidade como autoridade policial acerca da ocorrência de infração penal.

Após recebida a notitia criminis, a instauração do inquérito poderá se realizar de duas formas: a) através do termo circunstanciado, quando se tratar de crimes de menor potencial ofensivo, quando as cumulações das penas não ultrapassem 02 (dois) anos, sendo de competência dos juizados Especiais Criminais, conforme dispõe o artigo $69^{\circ}$ da Lei 9.099/95; b) através de inquérito Policial, quando às penas somadas ultrapassarem a pena de 02 (dois) anos, sendo de competência do Juízo Comum.

Posto isto, o Inquérito Policial compreende um conjunto de procedimentos que visam investigar a existência de um crime, descobrir e recolher as provas constante da materialidade e autoria do delito.

Reis Alexandre e Gonçalves Victor (2016, p.63) entendem que o inquérito é um "procedimento investigatório instaurado em razão da pratica de uma infração penal, composto por uma séria de diligências, que tem como objetivo obter elementos de prova."

Para Fernando Capez (2016, p. 148), o inquérito policial compreende:

\begin{abstract}
Conjunto de diligências realizadas pela polícia judiciária para a apuração de uma infração penal e de sua autoria, a fim de que o titular da ação penal possa ingressar em juízo (CPP, art. $4^{\circ}$ ). Trata-se de procedimento persecutório de caráter administrativo instaurado pela autoridade policial. Tem como destinatários imediatos o Ministério Público, titular exclui da ação penal pública (CF, art. 129, I), e o ofendido, titular da ação penal privada (CPP, art. 30); como destinatário mediato tem o juiz, que se utilizará dos elementos de informação nele constantes, para o recebimento da peça inicial e para a formação do seu convencimento quanto à necessidade de decretação de medidas cautelares.
\end{abstract}

Corroborando com os fatos acima narrados, a primeira caraterística do inquérito policial é que a autoridade competente para sua instauração é em regra a polícia judiciária, sendo o delegado o referido agente para tal ato, ou seja, é evidente que o inquérito é um procedimento administrativo, tendo em vista que é um procedimento realizado por uma autoridade, em que busca apenas indícios, provas do possível delito e autoria.

Posto isso, com relação à finalidade do inquérito policial, Marta Saad (2004, p. 161) leciona:

O inquérito policial traz elementos que 
não apenas informam, mas de fato instruem, convencem, tais como as declarações de vítimas, os depoimentos de testemunhas, as declarações dos acusados, a acareação, o reconhecimento, o conteúdo de determinados documentos juntados aos autos, as perícias em geral, a identificação datiloscópica, o estudo da vida pregressa, a reconstituição do crime.

Assim, o inquérito policial serve para averiguar os fatos descritos na notícia-crime, para posteriormente, ser encaminhado ao titular da ação penal. Entretanto, vale ressaltar que o Inquérito Policial tem como segunda característica a sua dispensa, ou seja, não é requisito indispensável para o oferecimento da denúncia ou da queixa, pois desde que o titular da ação penal tenha em mãos os elementos imprescindíveis o seu oferecimento e informações necessárias, o inquérito passa a ser absolutamente dispensável.

Tendo em vista o caráter informativo, o inquérito policial tem como sua terceira caraterística o caráter inquisitivo, ou seja, tem como procedimento as atividades persecutórias concentradas nas mãos de uma única autoridade, a qual, prescinde, para a sua atuação, podendo e devendo agir de ofício, com discricionariedade e realizando as atividades necessárias para os esclarecimentos do crime e da sua autoria.

Nesse sentido, conforme menciona o artigo $20^{\circ}$ do Código de Processo Penal: "A autoridade assegurará no inquérito o sigilo necessário à elucidação do fato ou exigido pelo interesse da sociedade". Resta claro que, por meio da leitura do dispositivo, a sua quarta caraterística é evitar a publicidade das provas colhidas ou aquelas que a autoridade pretende obter prejudique a apuração do ilícito. Entretanto, tal norma não pode ser interpretada de forma restritiva.

Finalmente, conforme menciona o artigo $9^{\circ}$ do Código de Processo Penal, a sua última característica é o inquérito tem que ser escrito, ou seja, todas a peças do inquérito policial serão num só processamento e reduzidas a escrito ou datilografadas e, neste caso rubricadas pela autoridade competente da lavratura do respectivo inquérito.

Percebe-se, assim, que o inquérito é um procedimento administrativo, com caráter inquisitivo, dirigido por uma autoridade, normalmente policial, que busca indícios e materialidade do delito, sendo posteriormente direcionado a autoridade competente, possuidora de legitimidade para possível ingresso da ação penal

\subsection{A condição do investigado como sujeito de garantias}

Para se falar em garantias fundamentais, tem que se falar em direitos fundamentais, pois um existe em virtude do outro. Nesse contexto, antigamente, os direitos fundamentais eram entendidos como os direitos do homem livre e isolado, direitos que estes homens possuíam em face do Estado, constituindo os direitos da liberdade da pessoa diante do Estado burguês. Essa concepção, correspondia aos chamados direitos fundamentais de primeira geração, tendo como princípios a liberdade, fraternidade e igualdade.

Segundo Bonavides (1997, p. 517-525), posteriormente surgiram os direitos de segunda geração, que eram os direitos culturais, sociais e econômicos, bem como os direitos coletivos. E mais tardiamente surgiram os direitos e garantias da terceira geração, relativos aos direitos de desenvolvimento, meio ambiente, patrimônio da humanidade, bem como à paz e à comunicação. Isto posto, é evidente que desde a Antiguidade os investigados sempre foram sujeitos de direitos e garantias perante o Estado, tendo em vista a sua hipossuficiência, uma vez que o Estado é sempre mais forte, o investigado merece um tratamento justo e com equidade.

Vale ressaltar, que em pleno século XXI tal situação não se extirpou, ao contrário, salvaguardou maiores garantias fundamentais para os investigados, haja vista que os investigados atualmente possuem direitos fundamentais mais abrangentes.

Tais direitos estão previstos em nossa Carta Magna, em seu artigo $5^{\circ}$ e seus respectivos incisos. Desse modo, o Estado em nome da democracia, deve além de limitar os direitos individuais, respeitar tais direitos para assim manter o equilíbrio entre o direito isolado de um cidadão e o direito à segurança da sociedade, ou seja, o Estado exerce um papel de garantias e limitações.

Para assegurar os direitos individuais, é fundamental e básico as limitações impostas ao poder Estatal, como por exemplo, os procedimentos exigidos para a instauração do inquérito policial, além do mais, os direitos e garantias individuais tem por origem combater os abusos pelo Estado, no qual se revela ao garantir assis- 
tência de advogado em um inquérito policial.

Tecnicamente, são direitos fundamentais os que estiverem previstos como tais na Constituição Federal. Vale ressaltar que, o fato de algum direito fundamental não ter constado na Constituição Federal, não exclui a possibilidade da ordem jurídica reconhecê-la.

Nesse diapasão, note-se o constante no art. $5^{\circ}, \S 2 .^{\circ}$, da Constituição Federal do Brasil: "Os direitos e garantias expressos nesta Constituição não excluem outros decorrentes do regime e dos princípios por ela adotados, ou dos tratados internacionais em que a República Federativa do Brasil seja parte".

Quanto aos direitos fundamentais e garantias, esclarece Jorge Miranda (1988):

Os direitos representam só por si certos bens, as garantias destinam se a assegurar a fruição desses bens; os direitos são principais, as garantias são acessórias. Os direitos permitem a realização das pessoas e inserem-se direta e imediatamente nas respectivas esferas jurídicas, já as garantias só nelas se projetam pelo nexo que possuem com os direitos; na acepção jurídica, os direitos declaram, as garantias estabelecem. (MIRANDA, 1988, p.89)

Ainda nesse sentido, Rui Barbosa (1934, p.356) leciona que os direitos individuais são aspectos ou manifestações da personalidade humana em sua existência subjetiva ou em relação à sociedade, enquanto garantias são as solenidades que tutelam alguns desses direitos contra os abusos do poder.

Pode-se dizer então que os direitos assentam na pessoa, independentemente do Estado, ou seja, são formas de agir, enquanto as garantias reportam-se ao Estado em relação aos atos praticados pelo indivíduo.

Portanto, os direitos fundamentais são, na prática, garantias fundamentais de outros direitos fundamentais.

Para Guilherme de Souza Nucci (2016):

São direitos individuais - porque inerentes à pessoa humana - o direito à liberdade de locomoção, garantido pelo devido processo legal e seus corolários; o direito à livre manifestação do pensamento e o direito à honra, garantidos pelo direito de resposta; os direitos à vida e à integridade física, garantidos pela proibição da pena de morte e da tortura, e assim sucessivamente. (NUCCl, 2016, p.66)

Entretanto, como aponta Vicente Greco Filho (1989, p. 40) "é bem difícil distinguir um direito e uma garantia."

Como por exemplo, o direito à liberdade física é fundamental e para amparar tal direito, surge a garantia de que ninguém será levado ao cárcere sem o devido processo legal. $\mathrm{E}$ até mesmo para dar-se um regular processo constitucional, surge a garantia da ampla defesa, que, por sua vez, é garantida pelo contraditório, essa garantia de ampla defesa também é garantida pelo direito à prova e pela não admissão, no processo, das provas ilícitas.

Em outro sentido, o ser humano tem direito a produzir, no processo criminal, quando acusado pelo Estado, uma ampla defesa e, para assegurar tal direito, surge a garantia instrumental do habeas corpus, como remédio constitucional, consagrado em nossa Carta Magna. Seguindo essa linha de raciocínio, Canotilho (1995, p. 520) afirma: "rigorosamente, as clássicas garantias são também direitos, embora muitas vezes se salientasse nelas o caráter instrumental de proteção dos direitos. As garantias traduziam-se quer no direito dos cidadãos a exigir dos poderes públicos a proteção dos seus direitos".

Corroborando com os conceitos apresentados, fica explícito que todos os indivíduos possuem direitos fundamentais, bem como são salvaguardadas as devidas garantias. Portanto, todos os direitos fundamentais devem ser rigorosamente observados pelo Estado que se pretenda democrático e de Direito.

Nesse diapasão, se um acusado deve possuir todos direitos e garantias fundamentais salvaguardados num processo criminal, o indivíduo que está sendo investigado em virtude de um possível ato infracional também deve possuir garantias específicas. Um exemplo, o acesso do advogado na investigação preliminar, o direito do investigado de estar acompanhado por seu advogado, garantias estas que servem para evitar que ocorra abusos de poderes por parte do Estado e coerção Estatal frente ao investigado.

\subsection{A dignidade da pessoa humana do inves- tigado}

A dignidade da pessoa humana é uma qualidade inerente ao indivíduo decorrente da 
própria condição de ser humano. Constitui um valor universal e está acima de qualquer diversidade sócio-cultural, não importando as diferenças físicas, psicológicas, intelectuais ou mesmo econômicas para que um indivíduo seja detentor de igual dignidade.

O princípio da dignidade da pessoa humana vem sendo assegurado desde a Declaração dos Direitos do Homem e do Cidadão, proclamada pela Organização das Nações Unidas de 1948. Com a promulgação da Constituição Federal, em 05 de outubro de 1988, o Brasil passou a salvaguardar garantias ao acusado, tais como os direitos sociais e individuais, o desenvolvimento, a igualdade, o bem-estar e a justiça social. Desse modo, a dignidade da pessoa humana consagrou-se como princípio máximo, além de ser fundamento da República introduzido no art. $1^{\circ}$, III da Carta Magna:

Art. $1^{\circ}$ - A República Federativa do Brasil, formada pela união indissolúvel dos Estados, dos Municípios e do Distrito Federal, constitui-se em Estado Democrático de Direito e tem como fundamento:

III - a dignidade da pessoa humana;

Nesse sentido, a dignidade da pessoa humana é para o Direito Processo Penal um alicerce, uma vez que todos os princípios do Processo Penal estão legitimados ao princípio do regime adotado por toda a nação, ou seja, a dignidade da pessoa humana.

O princípio, por si só, busca resguardar a integridade do indivíduo como pessoa e é no Processo Penal que essa proteção se concretiza. Atualmente o Estado não vem atendendo a condição de ser humano ao acusado, mas vem tratando-o como verdadeiro objeto do processo, em virtude da busca da verdade real, a pessoa humana se torna um objeto com prisões preventivas, que visam muito mais uma antecipação de pena do que a análise do caso concreto.

Ante o exposto, tendo em vista que a dignidade da pessoa humana é o valor básico de todos os outros direitos humanos, é imprescindível que os direitos existenciais da dignidade não sejam quebrados. Não há que se falar em mais ou menos dignidade, ou seja, o indivíduo acusado, investigado, indiciado não perde a sua dignidade, por pior que seja a sua conduta.

Conforme já dito, a dignidade da pessoa humana é um princípio constituído por lei que garante e exige que todo cidadão brasileiro esteja assegurado dos seus direitos sociais e individuais.

A propósito devem ser registradas as considerações de Carvalho, 2007, P. 549):

A dignidade da pessoa humana é o fundamento de todo o sistema dos direitos fundamentais, no sentido de que estes constituem exigências, concretizações e desdobramentos da dignidade da pessoa e que com base nesta é que devem aqueles ser interpretados.

Portanto, os direitos fundamentais são os direitos do homem escritos nos textos constitucionais, que conotam um direito positivado e constitucionalizado, pois além de fazerem parte da própria essência humana, são erigidos ao plano internacional.

Nesse sentido, afigura-se digna de registro a manifestação de Ingo Wolfgang Sarlet $(2008$, p. 88 - 89) ao dizer que "A dignidade da pessoa humana exige o reconhecimento e proteção dos direitos fundamentais de todas as dimensões, e se não reconheçam à pessoa humana e os direitos que lhes são inerentes, estar-se-á negando-lhe a própria dignidade".

Nos dizeres de Fernando Capez (2017, p.18): "a dignidade da pessoa humana é o valor à vida humana, como pedra angular do ordenamento jurídico, que deve nortear a atuação do interprete e aplicador do Direito, qualquer que seja o ramo da ciência que se deva possibilitar a concretização desse ideal no processo judicial".

Além do mais, para o Doutrinador GuiIherme de Souza Nucci (2016, p. 76) "a dignidade da pessoa humana é base sobre a qual todos os direitos e garantias individuais são erguidos e sustentados. Ademais, inexistiria razão de ser a tantos preceitos fundamentais não fosse o nítido suporte prestado à dignidade humana".

Ainda nos dizeres de Guilherme de Souza Nucci (2016, p. 76):

O Processo Penal constitui o amálgama do Direito Penal, pois permite a aplicação justa das normas sancionadoras. A regulação dos conflitos sociais, por mais graves e incômodos, depende do respeito aos vários direitos e garantias essenciais à formação do cenário ideal para a punição equilibrada e consen- 
tânea com os pressupostos do Estado Democrático de Direito, valorizando-se, acima de tudo, a dignidade humana.

Percebe-se que, o princípio da dignidade da pessoa humana atinge todos, sem distinção, conferindo-os um complexo conjunto de direitos e deveres que garantem a proteção de todo e qualquer ato contra a vida, além de salvaguardar a integridade física e psíquica.

\section{A LEI 13.245/16 E SUAS MUDANÇAS}

Em 12 de janeiro de 2016, foi publicado no Diário Oficial da União a promulgação da Lei 13.245/16, legislação está que além de alterar o artigo 7, XVI da Lei 8.906/14 (Estatuto da Ordem dos Advogados do Brasil), acrescentou o inciso XXI e os parágrafos $\S 10$, $\S 11$ e $\S 12$ da supracitada lei. Mas, o advento da lei não inovou drasticamente, apenas salvaguardou o que já estava previsto em nossas legislações, especialmente no artigo 5, LXIII da Constituição Federal:

\begin{abstract}
Art. $5^{\circ}$ Todos são iguais perante a lei, sem distinção de qualquer natureza, garantindo-se aos brasileiros e aos estrangeiros residentes no País a inviolabilidade do direito à vida, à liberdade, à igualdade, à segurança e à propriedade, nos termos seguintes:

LXIII - o preso será informado de seus direitos, entre os quais o de permanecer calado, sendo-lhe assegurada a assistência da família e de advogado.
\end{abstract}

Ante ao exposto, a lei trouxe apenas a ressalva da efetiva atuação do advogado nos procedimentos investigatórios, seja da esfera penal, administrativa e até mesmo as investigações realizadas pelo Ministério Público.

O objetivo principal do legislador ao promulgar a lei foi o de garantir ao cidadão, de forma ampla, princípios fundamentais e a ordem jurídica, evitando consequentemente, o abuso de poder por parte das autoridades competentes.

Com a alteração no inciso XVI, o dispositivo além continuar garantindo aos defensores o direito de acesso ao inquérito policial. Esses passaram a acompanhar todos os procedimentos investigatórios realizados por qualquer órgão competente. Entretanto, o acesso continua restrito quando se tratar de procedimentos sigilosos, momento que o advogado deverá apre- sentar procuração para o efetivo direito mencionado no inciso XVI, ou, quando houver riscos e comprometimento da eficiência e eficácia das diligências, tendo em vista, respectivamente, os textos acrescidos nos $\S 10$ e $\S 11$, em virtude da alteração do inciso XVI do Estatuto da OAB.

Além de incluir os parágrafos já mencionados, verificou-se também o advento do $\$ 12$, que trouxe como redação a possibilidade de responsabilização criminal e funcional do agente que negar-se a fornecer os documentos já anexados e concluídos no inquérito.

Nesse diapasão, o legislador acrescentou também o inciso XXI, que além de trazer a presença do advogado no interrogatório do atuado, ou seja, trazer a possibilidade do autuado estar acompanhado de advogado no momento de seu depoimento, trouxe também a possibilidade de nulidades dos atos caso seja desrespeitado os direitos assegurados pela legislação. Assim, as respectivas alterações trouxeram a garantia da não produção de provas ilícitas, aplicando-se por consequência a teoria da prova ilícita da derivação, teoria esta que consagra como nula as provas que forem produzidas diante uma ilegalidade e todos os atos que dela se originarem.

Ante o exposto, a maior divergência e discussão gerada pelo advento da Lei foi em virtude do inciso XXI do Estatuto da Ordem dos Advogados do Brasil, que passou a prever tal nulidade dos atos probatórios se decorressem em virtude de uma ilegalidade. Mas, vale ressaltar, que as nulidades das provas produzidas no inquérito só poderão ser anuladas quando trouxerem prejuízos para o investigado e quando efetivamente esse prejuízo for comprovado.

Nesse sentido, pode-se dizer que essa garantia trazida pela Lei foi para salvaguardar o direito do defensor, no interesse do representado, o acesso amplo aos elementos de prova que já estão documentados em procedimento investigatório, além de garantir ao investigado o mínimo de dignidade e garantias fundamentais, onde serão demonstrados e comprovados, detaIhadamente, em tópicos específicos.

\subsection{A garantia da participação da defesa}

Antes da edição da Lei 8.906/94 (Estatuto da OAB) trazida pela Lei $13.245 / 16$, já havia divergências no tocante à participação do advogado durante os interrogatórios policiais, pois na prática, alguns Delegados não permitiam sequer a presença do advogado, pelo fato de ter con- 
trovérsias sobre a existência de dispositivo legal que desse amparo a tal pretensão.

Entretanto, conforme já mencionado no tópico antecedente, mesmo com o advento da Lei 13.245/16, que acrescentou o inciso XXI no artigo $7^{\circ}$ da Lei. 8.906/94 - Estatuto da Ordem dos Advogados do Brasil, que trouxe a facultada presença do advogado no inquérito policial, não extinguiu a discussão. Posto isso, o inciso XXI tem a seguinte redação:

Art. $7^{\circ}$ São direitos do advogado: (...) $X X I$ - assistir a seus clientes investigados durante a apuração de infrações, sob pena de nulidade absoluta do respectivo interrogatório ou depoimento e, subsequentemente, de todos os elementos investigatórios e probatórios dele decorrentes ou derivados, direta ou indiretamente, podendo, inclusive, no curso da respectiva apuração:

a) apresentar razões e quesitos;

b) (VETADO).

Tendo em vista a introdução o referido inciso, o advogado passou a ter o direito de estar presente e, inclusive, de fazer perguntas, recebendo então, amparo expresso e legal. Mas, e como seria essa presença? Ela passaria a ser obrigatória a fim de garantir ao investigado maior amplitude de suas garantias fundamentais? O inquérito passaria a ter um caráter acusatório?

Nesse sentido, vale transcrever o posicionamento do doutrinador Renato Brasileiro (2016, p. 134-135):

As mudanças legislativas produzidas pela Lei n. 13.245/16 não têm o condão de afastar a natureza inquisitorial das investigações preliminares, nem tampouco de tornar obrigatória a presença de advogado durante o interrogatório policial. Na verdade, preservada esta natureza, o que houve foi a outorga de um viés mais garantista à investigação preliminar, buscando-se garantir os direitos fundamentais do investigado.

Posto isso, a Lei $n^{\circ} 13.245 / 16$ não introduziu nenhuma novidade no ordenamento jurídico pátrio, na verdade, simplesmente positivou o que a Constituição Federal sempre assegurou, ou seja, a assistência de advogado ao preso $\left(\mathrm{CF}\right.$, art. $\left.5^{\circ}, \mathrm{LXIII}\right)$, conforme já mencionado o tópico anterior.
Ainda nos dizeres de Renato Brasileiro (2016, p. 135):

Se a força normativa do referido preceito constitucional jamais foi suficiente para tornar cogente a presença de advogado por ocasião da realização de interrogatórios policiais, é no mínimo estranho que a simples reprodução desse mesmo preceito em uma lei ordinária teria o condão de passar a exigir sua presença. De mais a mais, fosse necessária a presença de advogado no interrogatório policial, referida mudança legislativa deveria ter sido introduzida no âmbito do Código de Processo Penal, diploma normativo que regulamenta o interrogatório policial, e não no Estatuto da Ordem dos Advogados do Brasil.

Mas, e se o advogado está presente no momento do interrogatório policial? Este terá o seu direito negado? Nesse sentido Brasileiro (2016, p. 135), ensina que: "Se o advogado estiver presente no interrogatório policial não se pode negar o direito de assistir a seu cliente, sob pena de evidente violação à garantia fundamental do art. $5^{\circ}$, LXIII, da CF."

Nesse caso, vale-se dizer, que presente o advogado, e negado o seu direito de assistir a seu cliente investigado, restará caracterizada a ilegalidade do interrogatório policial e, por consequência, de todos os elementos informativos e probatórios dele derivados, direta ou indiretamente, conforme a teoria dos frutos da árvore envenenada - CPP, art. 157, $\S 1^{\circ}$, objeto de estudo deste trabalho.

Ademais, se o próprio Supremo Tribunal Federal entende conforme súmula vinculante $n^{\circ}$ 5 , que "a falta de defesa técnica por advogado no processo administrativo disciplinar não ofende a Constituição", é no mínimo contraditório concluir que, a partir da vigência da Lei $n^{0} 13.245 / 16$, o interrogatório policial seja considerado válido tão somente quando o investigado estiver assistido por profissional da advocacia.

Em outras palavras, se não há necessidade de um defensor no curso de um processo administrativo disciplinar, de qual pode resulta a aplicação de sanções relativamente severas, tais como suspensão, exoneração, perda de função, é de se estranhar a obrigatoriedade de defensor durante a realização de um interrogatório policial, do qual jamais será possível a aplicação 
imediata de uma sanção. A inserção do inciso XXI no art. $7^{\circ}$ da Lei $n^{\circ} 8.906 / 94$, não fez com que a investigação preliminar perdesse a sua natureza inquisitiva, ou melhor, na verdade, ganhou um viés garantista, ou seja, respaldado de dignidade e garantias fundamentais.

\subsection{0 contraditório}

Na concepção originária do princípio do contraditório, entendia-se que, bastasse a informação conferida para o acusado e a sua possível reação para que se efetivasse a aplicação do contraditório. No entanto, com as alterações legislativas e com a concepção do princípio da isonomia, bem como com a superação da mera igualdade formal e a busca de uma igualdade substancial, produziu a necessidade de se igualar os desiguais, repercutindo assim no âmbito do princípio do contraditório.

Desde então, o contraditório, deixou de ser visto como uma mera possibilidade de participação, para se transformar em uma realidade.

Atualmente, há de se assegurar uma real e igualitária participação dos sujeitos processuais ao longo de todo o processo, assegurando a efetividade e plenitude do contraditório, tendo como denominação contraditório efetivo e equilibrado.

No entendimento de Gustavo Henrique Righi Ivahy Badaró (2008, p. 1-36) houve, assim, uma dupla mudança, subjetiva e objetiva. Segundo o autor, quanto ao seu objeto, deixou de ser o contraditório uma mera possibilidade de participação de desiguais, passando a se estimular a participação dos sujeitos em igualdade de condições. Subjetivamente, porque a missão de igualar os desiguais é atribuída ao juiz e, assim, o contraditório não só permite a atuação das partes, como impõe a participação do julgador.

Portanto, é evidente que em um primeiro momento, o contraditório limitava-se ao direito à informação e à possibilidade de reação, e posteriormente, o contraditório passou a ser analisado também no sentido de se assegurar o respeito à paridade de tratamento, haja vista que de nada adianta se assegurar à parte a possibilidade formal de se pronunciar sobre os atos da parte contrária; se não lhe são outorgados os meios para que tenha condições efetivas e reais de contrariá-los.

O princípio do Contraditório é a possibilidade da parte contrária se manifestar em desfavor de uma acusação imputada. Tal princípio deve assegurar sua manifestação efetiva e real, pois, o equilíbrio entre a acusação e defesa, que devem estar munidas de forças similares. Portanto, o contraditório somente pode ser eficaz se os ambas as partes possuírem os mesmos poderes.

Nesse diapasão, Ada Pelegrine Grinover (1992, p.63) nos ensina que a "defesa e contraditório estão indissoluvelmente ligados, pois é do contraditório que nasce o exercício da defesa". A defesa, assim, garante o contraditório, mas também por este se manifesta e é garantida. Isto posto, o Princípio encontra-se respaldado na Constituição Federal, em seu artigo $5^{\circ}$, inciso LV, informando que "aos litigantes, em processo judicial ou administrativo, e aos acusados em geral são assegurados o contraditório e ampla defesa, com os meios e recursos a ela inerentes."

Em um conceito genérico, o Princípio do Contraditório é como a garantia de participação no processo como meio de permitir a contribuição das partes para a formação do convencimento do juiz, ou seja, é garantir o direito à informação de qualquer fato ou alegação contrária ao interesse das partes e o direito à reação a ambos, vistos, assim, como garantia de participação.

Joaquim Canuto Mendes de Almeida (1973, p. 82), compreende o Princípio do Contraditório como a "ciência bilateral dos atos ou termos do processo e a possibilidade de contrariá-los. " De acordo com o autor, o núcleo fundamental do contraditório estaria ligado "à discussão dialética dos fatos da causa, devendo se assegurar a ambas as partes, e não somente à defesa, a oportunidade de fiscalização recíproca dos atos praticados no curso do processo."

Isto posto, para ter o devido processo legal, tem que estar presente o contraditório, haja vista que é um requisito de validade do processo, na medida em que a sua não observância é passível até de nulidade absoluta, quando em prejuízo do acusado.

Nesse diapasão, os elementos do contraditório são: 1) direito à informação; 2) direito de participação. Portanto, o contraditório seria, assim, a necessária informação às partes e a possível reação a atos desfavoráveis, não podendo cogitar da existência de um processo penal eficaz e justo sem que a parte adversa seja cientificada da existência da demanda ou dos argumentos da parte contrária. 
Daí que surge os meios de comunicação dos atos processuais: citação, intimação e notificação. $E$ ainda que o acusado não tenha interesse em oferecer reação à pretensão acusatória, o próprio ordenamento jurídico impõe a obrigatoriedade de assistência técnica de um defensor, conforme dispõe o próprio o artigo 261 do Código de Processo Penal que nenhum acusado, ainda que ausente ou foragido, será processado ou julgado sem defensor.

Entretanto, vale ressaltar, que prevalece tanto na doutrina, quanto na jurisprudência o entendimento de que a observância do contraditório só é obrigatória, no processo penal, ou seja, na fase processual, e não na fase investigatória, no inquérito policial, pois este é apenas um procedimento meramente informativo, tendo como natureza administrativa.

Seguindo a linha de raciocínio, não há contraditório no inquérito policial, porque conforme já mencionado o disposto no art. $5^{\circ}$, LV da Carta Magna, a observância do contraditório ocorre apenas em processo judicial ou administrativo. Logo, considerando-se que o inquérito policial é tido como um procedimento administrativo, destinado à colheita de elementos de informação quanto à existência do crime e quanto à autoria ou participação, não há falar em observância do contraditório na fase preliminar de investigações, dado que o Inquérito Policial não é um processo, mas um procedimento.

Nesse sentido, conforme o artigo 155, caput do Código de Processo Penal: "O juiz formará sua convicção pela livre apreciação da prova produzida em contraditório judicial, não podendo fundamentar sua decisão exclusivamente nos elementos informativos colhidos na investigação, ressalvadas as provas cautelares, não repetíveis e antecipadas". Ou seja, a leitura do artigo é clara e objetiva ao dizer que o juiz não poderá se fundamentar apenas nos elementos informativos colhidos durante a investigação preliminar; durante o inquérito policial.

Além do mais, a palavra prova só pode ser usada para se referir aos elementos de convicção produzidos, em regra, no curso do processo judicial, e, por consequência, com a necessária participação das partes, sob enfoque aos princípios do contraditório e da ampla defesa. Assim, a prova há de ser produzida não só com a participação do acusador e do acusado, como também mediante a direta e constante supervisão do órgão julgador. Respeitando assim, a observância do contraditório e devido processo legal. Portanto, junto ao princípio da ampla defesa, institui-se como a pedra fundamental de todo processo e, particularmente, do processo penal.

\subsection{A ampla defesa}

Consagrada também no art. $5 .^{\circ}$, LV da Constituição Federal, a ampla defesa traduz o dever que assiste ao Estado de facultar ao acusado toda a defesa possível quanto à imputação que the foi realizada.

A ampla defesa sob a ótica que privilegia o interesse do acusado, é vista como um direito, todavia, se for analisar com enfoque ao interesse geral de um processo justo, é vista como garantia.

Portanto, entende-se que a ampla defesa é uma garantia conferida ao acusado por ser considerado hipossuficiente, uma vez que o Estado possui órgãos constituídos e preparados, além de valerem-se de informações e dados de todas as fontes as quais têm acesso, conforme já dito anteriormente neste artigo.

Nesse contexto, Renato Brasileiro (2016, p. 129) entende que:

Com a ampla defesa há o tratamento mais justo e gera inúmeros direitos exclusivos do réu, como é o caso de ajuizamento de revisão criminal, bem como a oportunidade de ser verificada a eficiência da defesa pelo magistrado, que pode desconstituir o advogado escolhido pelo réu, fazendo-o eleger outro ou nomeando-Ihe um dativo, entre outros.

E, para Fernando Capez (2016, p. 89), "em virtude da ampla defesa, admite-se que o acusado seja formalmente tratado de maneira desigual em relação à acusação, delineando o viés material do princípio da igualdade". O Doutrinário afirmar ainda, que o investigado tem como defesa "a existência de recursos privativos da defesa, a proibição da reformatio in pejus, a regra do in dubio pro reo, a previsão de revisão criminal, privilégios estes que são reunidos no princípio do favor réu". Portanto, é evidente que ao acusado são outorgados diversos privilégios em detrimento da acusação.

No momento que a Constituição Federal assegura aos litigantes, em processo judicial ou administrativo a ampla defesa, ocorre a abrangência de proteções, como por exemplo a direito 
à defesa técnica, direcionada ao procedimento processual e à autodefesa, interligada na defesa material do delito.

Ante o exposto, segundo os posicionamentos doutrinários, também é possível subdividir a ampla defesa sob dois aspectos, o positivo que se realiza na efetiva utilização dos instrumentos, dos meios e modos de produção, em que há o esclarecimento ou confrontação de elementos de prova quanto à materialidade da infração criminal e a autoria. Além do negativo, que consiste na não produção de elementos probatórios de elevado risco ou potencialidade danosa à defesa do réu.

Por fim, a ampla defesa guarda intrínseca relação com o direito ao contraditório, além de também não ter sua aplicação direta no inquérito policial. No que tange a ampla defesa, ela garante o contraditório e por ele se manifesta. Ambos se confundem em razão de que o exercício da ampla defesa, só é possível em virtude de um dos elementos que compõem o contraditório, o qual é o direito à informação. Além disso, a ampla defesa se exprime por intermédio do segundo elemento pertencente ao contraditório, a reação.

Nesse sentido, Ada Pelegrine Grinover (1992), defende que a ampla defesa é sequela do contraditório:

Se por intermédio do contraditório se reconhece a absoluta igualdade entre as partes, por meio da ampla defesa que tal igualdade ganhará corpo, tornando-se efetiva e palpável. A ampla defesa consiste, portanto, na possibilidade do réu em contraditar por completo a acusação. (GRINOVER, 1992, p.63)

Desse modo, tendo em vista a relação direta entre os princípios, vale demonstrar o entendimento doutrinário de Gustavo Henrique Badaró (2009, p. 37), em que o autor leciona a principal distinção entre a ampla defesa e contraditório:

É evidente quando é possível violar-se o contraditório, sem que se lesione o direito de defesa. Não se pode esquecer que o princípio do contraditório não diz respeito apenas à defesa ou aos direitos do réu. O princípio deve aplicar-se em relação a ambas as partes, além de também ser observado pelo próprio juiz. Deixar de comunicar um determinado ato processual ao acusador, ou impedir-lhe a reação à determinada prova ou alegação da defesa, embora não represente violação do direito de defesa, certamente violará o princípio do contraditório. O contraditório manifesta-se em relação a ambas as partes, já a defesa diz respeito apenas ao réu.

Note-se que, a ampla defesa se refere à garantia que é concedida ao réu de se valer de amplos e extensos métodos para se defender da imputação feita pela acusação, já o contraditório existe em virtude da existência das ambas as partes do processo.

\subsection{A alteração do artigo $7^{\circ}$, XIV do estatuto da Ordem dos Advogados do Brasil}

Como já dito anteriormente, em tópico específico, o advento da Lei 13.245/16 alterou o artigo 7, XIV do Estatuto da Ordem dos Advogados do Brasil (Lei $n^{\circ}$. 8.906/94), salvaguardando o que já estava previsto em nosso ordenamento jurídico. Com a supracitada alteração houve apenas a abrangência na possibilidade de o defensor em poder examinar os documentos colhidas durante a tramitação do inquérito.

Isto posto, far-se-ia necessário a transcrição do inciso XIV antes da Lei 13.245/16, cujo se encontra previsto no artigo $7^{\circ}$ do Estatuto da OAB:

Art. $7^{\circ}$ São direitos do advogado: (...) XIV - examinar em qualquer repartição policial, mesmo sem procuração, autos de flagrante e de inquérito, findos ou em andamento, ainda que conclusos à autoridade, podendo copiar peças e tomar apontamentos; (grifo meu)

E, após a promulgação da Lei 13.245/16, o art. $7^{\circ}$, inciso XIV do Estatuto da OAB, passou ter a seguinte redação:

Art. $7^{\circ}$ São direitos do advogado: (...) XIV - examinar, em qualquer instituição responsável por conduzir investigação, mesmo sem procuração, autos de flagrante e de investigações de qualquer natureza, findos ou em andamento, ainda que conclusos à autoridade, podendo copiar peças e tomar apontamentos, em meio físico ou digital; (grifo meu) 
Tal alteração foi necessária, pois o legislador levou em conta que na época em que o Estatuto da OAB foi promulgado, em 04 de julho de 1994 , somente a autoridade policial conduzia as investigações para apuração da materialidade e autoria do delito. Porém, atualmente a situação se alterou, pois, diversos órgãos começaram a realizar tais investigações. Pode-se citar como rol exemplificativo, o Ministério Público, as Comissões Parlamentares de Inquérito, a Comissão de Valores Mobiliários (CVM), entre outros.

Dessa forma, o texto anterior contido no inciso XIV mostrava-se desatualizado, pois falava-se tão somente em "repartição policial" e não em "instituição responsável", mas com a mudança do inciso, os advogados passaram a ter o direito expresso, podendo esses examinar os autos dos procedimentos de investigação de qualquer natureza e em qualquer instituição.

Ademais, o direito ao acesso as investigações já concluídas existia antes mesmo da alteração da Lei 8.906/94, conforme a súmula 14 do STF: "É direito do defensor, no interesse do representado, ter acesso amplo aos elementos de prova que, já documentados em procedimento investigatório realizado por órgão com competência de polícia judiciaria, digam respeito ao exercício do direito de defesa".

Desse modo, antes mesmo da alteração do art. $7^{\circ}$ do Estatuto da OAB, o Supremo Tribunal Federal decidiu no Recurso Extraordinário 593727/MG que "o Ministério Público dispõe de competência para promover, por autoridade própria, e por prazo razoável, investigações de natureza penal, devendo o Ministério Público respeitar as prerrogativas dos advogados previstas no art. $7^{\circ}$ da Lei 8.906/94". Isso mostra verdadeira consonância da decisão do STF com a promulgação da Lei 13.245/16, pois antes mesmo de alterar o inciso XIV, o STF já havia assegurado aos advogados seus direitos, mesmo em investigação criminal fora do âmbito policial, no caso, realizados dentro do Ministério Público.

Na nova redação, o legislador deixou claro que o advogado não só poderá examinar os autos de qualquer procedimento investigatório, como também poderá examinar nos autos em qualquer instituição responsável.

Já a inserção da parte final do inciso, em que traz a informação "em meio físico ou digital" diz respeito ao direito conferido ao advogado, podendo este tirar cópias ou realizar aponta- mentos, tanto em meio físico como digital, sendo assegurado a discricionariedade em poder tirar fotos dos autos ou realizar qualquer outro meio físico ou digital.

Além da alteração do artigo $7^{\circ}$, inciso XVI, ocorreu a promulgação de novos parágrafos, como já dito no decorrer deste artigo. Posto isso, o advento do $\S 10$ no artigo $7^{\circ}$ do Estatuto da OAB, trouxe como informação de que "Nos autos sujeitos a sigilo, deve o advogado apresentar procuração para o exercício dos direitos de que trata o inciso XIV". Desse modo, é evidente que a leitura do parágrafo é autoexplicativa, uma vez que, por via de regra, o advogado não precisa de procuração para ter acesso aos autos de investigação. No entanto, caso os autos que estejam sujeitos a sigilo, será necessária a procuração.

Outra novidade trazida pela Lei é a vinda do $\S 11$ no artigo $7^{\circ}$ do Estatuto da OAB:
$\S 11$. No caso previsto no inciso XIV, a autoridade competente poderá delimitar o acesso do advogado aos elementos de prova relacionados a diligências em andamento e ainda não documentados nos autos, quando houver risco de com- prometimento da eficiência, da eficácia ou da finalidade das diligências.

Posto isto, o parágrafo supracitado foi introduzido com o objetivo de garantir a eficácia das diligências, pois se determinadas informações que ainda não foram concluídas e anexadas aos autos da investigação fossem informadas para o advogado, estas correram o risco de serem frustradas. Assim, o legislador se salvaguardou para que, nestas hipóteses, a autoridade tenha a discricionariedade para autorizar ou não o acesso a essas diligências em andamento.

Por fim, a Lei também acrescentou o $§ 12$ ao artigo $7^{\circ}$ do Estatuto da OAB:

§ 12. A inobservância aos direitos estabelecidos no inciso XIV, o fornecimento incompleto de autos ou o fornecimento de autos em que houve a retirada de peças já incluídas no caderno investigativo implicará responsabilização criminal e funcional por abuso de autoridade do responsável que impedir o acesso do advogado com o intuito de prejudicar o exercício da defesa, sem prejuízo do direito subjetivo do advogado de requerer acesso aos autos ao juiz competente. 
Corroborando com o parágrafo acima mencionado, caso a mesma autoridade negue o direito ao advogado de acessar os autos, fornecer os autos de forma incompleta, e até mesmo retirar peças que já foram concluídas ao processo investigatório, esta a autoridade, nestes casos, poderá sofrer responsabilização criminal e funcional por abuso de autoridade, nos termos do art. $3^{\circ}$, alínea "J", da Lei $n^{\circ} 4.898 / 65$ : Constitui abuso de autoridade qualquer atentado: j) aos direitos e garantias legais assegurados ao exercício profissional.

$E$ vale ressaltar ainda, que além da responsabilização da autoridade, o advogado poderá peticionar ao juiz requerendo o acesso completo aos autos.

\section{CONSIDERAÇÕES FINAIS}

O inquérito policial é uma peça de informação que tem como finalidade investigar um possível ato ilícito. As características marcantes do inquérito como a inquisitoriedade e o sigilo foram assuntos para diversas discussões. Uma análise dos princípios do contraditório e a ampla defesa foi feita em função do caráter inquisitivo do inquérito policial, já que não prevê esses princípios na fase preliminar. Entretanto, sempre respeitando o controle da legalidade e os direitos individuais do indiciado. O sigilo nas investigações também foi alvo de ponderações, no qual, chegou-se a conclusão de que este sigilo não pode ser interpretado de forma restritiva, como era visto anteriormente, uma vez que o advento da Lei $n^{\circ} 13.245 / 16$, traz como prerrogativa do advogado o seu acesso aos autos do inquérito policial, estando ele constituído na causa ou não. Aliás, a própria Súmula $n^{\circ} 14$ da Suprema Corte já admitia o acesso ao inquérito policial sigiloso para o advogado devidamente constituído na causa. Desse modo, a nova Lei $n^{\circ} 13.245 / 16$ apenas ressaltou o acesso do advogado aos autos.

Porém, esse acesso do advogado aos autos continua limitado, uma vez que o defensor só poderá ter acesso às provas e discussões já anexas no inquérito, como também na situação em que exige procuração, que são os casos de sigilo, ou então, os casos em que o acesso aos autos possa causar risco de comprometimento da eficiência das diligências em andamento ou aquelas que ainda não foram documentadas nos autos. O que mostra nesse caso o Direito Públi- co sobressaindo ao Privado.

Ademais, o direito de assistência jurídica, continua sendo facultativa, ou seja, não há que se falar em obrigatoriedade ao se tratar de presença do advogado nas investigações criminais, mas uma vez que o advogado esteja presente no momento do interrogatório, não há porque negar-se a sua entrada para acompanhamento de seu cliente e, por consequência, verifica-se que não houve alteração ao caráter inquisitivo do inquérito.

Nota-se que, com o advento da Lei houve uma democratização na investigação, conferindo transparência aos atos praticados nesta fase, constituindo, assim, um avanço para a investigação criminal.

Conclui-se que mesmo após o advento da Lei $n^{\circ} 13.245 / 16$ que alterou o artigo $7^{\circ}$ da Lei $n^{\circ} 8.906 / 94$, o caráter inquisitivo do inquérito não sofreu alterações, mas apenas salvaguardou o que já estava previsto nas legislações, trazendo assim um caráter mais garantista ao investigado e salvaguardando o direito ao advogado.

\section{REFERÊNCIAS}

ALMEIDA, J. C. M. Princípios fundamentais do processo penal. São Paulo: Editora Revista dos Tribunais, 1973. p. 82.

BRASIL. Constituição (1988). Constituição da República Federativa do Brasil: promulgada em 5 de outubro de 1988. 8. ed. São Paulo: Revista dos Tribunais, 2003.

, Lei n 8.906, de 04 de julho de 1994. Dispõe sobre o Estatuto da Advocacia e a Ordem dos Advogados do Brasil (OAB). Diário Oficial da República Federativa do Brasil, Brasília.

, Lei $n^{\circ} 13.245$, de 12 de janeiro de 2016. Altera o art. 7o da Lei no 8.906, de 4 de julho de 1994 (Estatuto da Ordem dos Advogados do Brasil). Diário Oficial da República Federativa do Brasil, Brasília.

. VADE MECUM. Obra coletiva e autoria da Editora Rideel com colaboração de Anne Angher. Código de Processo Penal: 1941. 21 ed. atual. e ampl - São Paulo: Saraiva, 2015, p. 407.

BADARÓ, G. H. Correlação entre acusação e sentença. 2. ed. São Paulo: Editora Revista dos 
Tribunais, 2009, p. 37.

BADARÓ, G. H.; RIGHI, I. Direito processual penal. Rio de Janeiro: Editora Elsevier, 2008. Tomo 1. p. 1-36.

BARBOSA, R. Comentários à Constituição Federal Brasileira. Org. Homero Pires. São Paulo: Saraiva, 1934. v. 6, p. 356.

BONAVIDES, P.Curso de direitoconstitucional. 7. ed. São Paulo: Malheiros, 1997, p. 517 - 525.

CANOTILHO, J. J. G. Direito constitucional. 6. ed. Coimbra: Almedina, 1995, p. 520.

CAPEZ, F. Curso de processo penal / Fernando Capez. - 23. ed. - São Paulo: Saraiva, 2016, p. 40-99.

CARVALHO, K. G. C. Direito Constitucional. 13. ed. Belo Horizonte: Del Rey, 2007, p. 549.

GRECO FILHO, V. Tutela constitucional das liberdades. São Paulo: Saraiva, 1989, p. 40.

LOPES JUNIOR, A. Sistemas de Investigação no Inquérito Policial. 3 ed. Rio de Janeiro: Lúmen Júris, 2005, p. 135-162.

LIMA, R. B. Manual de processo penal: volume único - 4. ed. rev., ampl. e atual. - Salvador: Ed. JusPodivm, 2016.

MEHMERI, A. Inquérito Policial: Dinâmica. 1 ed. São Paulo: Saraiva, 1997, p. 04.

MIRANDA, J. Manual de direito constitucional. 3. ed. Coimbra: Coimbra Ed. 1988. t. IV, p. 89.

NUCCI, G. de S. Manual de processo penal e execução penal. 13. ed. rev., atual. e ampliada. - Rio de Janeiro: Forense, 2016, p. 76.

PELLEGRINI G. A.; SCARANCE F. A.; GOMES FILHO, A. M. As nulidades no Processo Penal, 2. ed. Ed. Malheiros, São Paulo, 1992, p. 63.

REIS, A. C. A.; GONÇALVES, V. E. R.; LENZA, P. coordenador. Direito processual penal esquematizado. 5. ed. São Paulo: Saraiva, 2016, p. 63.

SAAD, M. O Direito de Defesa no Inquérito

Policial. v. 9. São Paulo: RT, 2004, p. 161.
SARLET, I. W. Dignidade da Pessoa Humana e Direitos Fundamentais na Constituição Federal de 1988. 6. ed. Porto Alegre: Livraria do Advogado, 2008, p. 88-89.

\section{LA LEY 13.245/16 Y EL CARÁCTER INQUISITIVO DEL EXPEDIENTE POLICIAL}

Resumen: Se ha buscado con esta investigación analizar el expediente policial con sus características y peculiaridades, buscando demostrar los principales cambios y discusiones oriundos de la Ley 13.245/16. A priori, es necesario observar los principios constitucionales, con énfasis en el contradictorio y amplia defensa. Considerándose que existe una discusión entre profesionales del área de derecho, donde unos dicen que esa ley generó ventajas para investigados, y otros dicen ser solamente ampliación del derecho de acceso al expediente por parte de los profesionales. Tras un análisis minucioso de las ponderaciones del adviento de la Ley 13.245/16, que innovó principalmente la cuestión del acceso al expediente por parte del abogado, el sigilo relativo al expediente y la nulidad de los actos probatorios. Se evidenció que el abogado tendrá más acceso al expediente policial, tendrán acceso solamente a las pruebas y discusiones adjuntas en el expediente, que los cuestionamientos al investigado solo se harán tras la renuncia de la asistencia jurídica. Todavía, es necesario que esa ley sea más estudiada, para que haya equilibrio entre el acceso y el sigilo de expediente, para no perjudicar su andamiento, ni la utilidad de sus pruebas, pero es necesario asegurar a los investigados más protección al principio de no autoincriminación. Sobre todo, se percibe que el proceso inquisitorial no sufrirá cambios significativos, ni dejará de ser inquisitivo, pues no existen, en estos casos, los principios del contradictorio y de amplia defensa. Para la realización de este estudio, se utilizó como metodología la investigación bibliográfica con la utilización de material específico entre ellos, documentos, monografías, disertaciones y libros, siendo este último la principal fuente primaria.

Palabras clave: Amplia Defensa; Contradictorio; Expediente Policial; Proceso Penal; Sigilo del Expediente. 